\title{
PENDAMPINGAN PENGEMBANGAN PRODUK BARU PADA INDUSTRI KECIL MENENGAH PRODUK MAKANAN RINGAN GUNA PENINGKATAN DAYA SAING
}

\author{
Lithrone Laricha Salomon $^{1}$, Wilson Kosasih ${ }^{1}$ dan I Wayan Sukania ${ }^{1}$ \\ ${ }^{1}$ Jurusan Teknologi Industri, Prodi Teknik Industri, Universitas Tarumanagara Jakarta \\ Email: lithrones@ft.untar.ac.id
}

\begin{abstract}
ABSTRAK
Sekarang ini, Industri Kecil Menengah (IKM) produk makanan ringan mengalami peningkatan yang cukup signifikan. Akan tetapi pemasaran produknya dirasakan belum mampu bersaing. Adapun lemahnya daya saing dari IKM tersebut disebabkan oleh desain kemasan produk yang kurang menarik; jalur distribusi produk yang kurang baik; strategi promosi yang masih tradisional serta belum memiliki jejaring bisnis yang luas. Oleh karena itu, dilakukan kegiatan pendampingan pada salah satu IKM tersebut yang bertujuan untuk mengembangkan produk baru sesuai dengan preferensi konsumen dengan penelitian awal yang menggunakan metode analisis konjoin. Produk IKM ini adalah makanan ringan yang dikenal dengan nama telur gabus dengan merk HALISA Hasil dari pengembangan produk dievaluasi secara berkala berdasarkan peningkatan penjualan yang ada. Pada akhirnya studi ini menunjukan terdapat pengaruh positif dari pengembangan produk baru terhadap peningkatan penjualan.
\end{abstract}

Kata kunci: IKM; Makanan ringan; Pengembangan produk baru; Peningkatan penjualan.

\section{PENDAHULUAN}

Berdasarkan penelitian yang dilakukan oleh Mondeles tahun 2018 dikatakan bahwa minat konsumsi makanan ringan pada masyarakat Indonesia cukup tinggi. Hasil dari responden yang diteliti oleh mondeles adalah frekuensi dari konsumsi makanan ringan adalah hingga tiga kali sehari.(Mondeles, 2018). Melihat besarnya jumlah konsumen dari produk makanan ringan di Indonesi maka produsen diharapkan dapat meningkatkan loyalitas konsumen terhadap produk yang ada dengan cara memenuhi kebutuhan konsumen baik dari segi kualitas produk secara umum dalam hal ini rasa dan juga atribut pendukungnya sehingga penjualan produk makanan ringan tersebut dapat terus meningkat.

Masalah yang ditemukan saat ini adalah produsen belum bisa memenuhi kebutuhan konsumen dalam berbagai aspek secara menyeluruh. Selain itu produsen juga belum bisa mengidentifikasikan atribut yang menjadi pertimbangan utama masyarakat dalam membeli produk makanan ringan. Hal ini menyebabkan lemahnya daya saing dari IKM produk makanan ringan. Lemahnya daya saing dari IKM makanan ringan tersebut antara lain disebabkan oleh desain kemasan produk yang kurang menarik; jalur distribusi produk yang kurang baik; strategi promosi yang masih tradisional serta belum memiliki jejaring bisnis yang luas. Beberapa hal tersebut menyebabkan tingkat penjualan produk makanan ringan yang dihasilkan oleh IKM tersebut belum dapat mengalami peningkatan secara signifikan.

Salah satu produk makanan ringan yang akan dilakukan pengembangan lebih lanjut adalah produk telur gabus. Masyarakat juga mengenal camilan ini dengan nama kue widaran atau bidaran, namun sebenarnya bahan dasarnya berbeda karena widaran menggunakan tepung beras ketan. Telur gabus banyak disukai oleh masyarakat dari berbagai golongan usia dan ekonomi. IKM Telur Gabus yang akan dikembangkan adalah Telur Gabus hasil dari produksi IKM HALISA. IKM HALISA adalah salah satu contoh produsen telur gabus berskala kecil menengah. Telur gabus ini memiliki bahan dasar tambahan keju yang menciptakan rasa lebih gurih dibanding telur gabus pada umumnya. Walaupun masih tergolong baru, namun kualitas rasa yang gurih dan renyah di 
setiap telur gabus selalu diperhatikan. Upaya yang dilakukan untuk meningkatkan kepercayaan konsumen adalah dengan cara memenuhi kebutuhan konsumen melalui informasi tentang preferensi konsumen terhadap makanan ringan telur gabus. Salah satu metode untuk menggambarkan preferensi konsumen adalah conjoint analysis.

Penggunaan conjoint analysis juga mampu mengevaluasi produk komplek yang dilihat dari konteks keputusan konsumen yang realistis. Selain itu, dapat diketahui penilaian tingkat kepentingan masing-masing atribut dimana konsumen hanya mengevaluasi profil produk yang sedikit (Hooley et al, 2012). Dalam memahami keputusan konsumen ada dua tujuan dasar conjoint analysis yaitu menentukan kontribusi atribut serta levelnya dalam menentukan kebutuhan konsumen dan membentuk model yang valid dari penilaian konsumen sehingga memungkinkan untuk memprediksi penerimaan konsumen dari kombinasi atribut (Hair, 2009).

\section{METODE PELAKSANAAN PENGABDIAN KEPADA MASYRAKAT (PKM)}

Metode Pelaksanaan yang dilakukan pada Kegiatan PKM ini terdiri atas empat tahapan, yaitu: Tahap Perencanaan, Tahap Pengorganisasian, Tahap Pelaksanaan, dan Tahap Pengendalian. Tahapan yang pertama adalah Tahap Perencanaan. Tahap ini adalah tahap awal mulai dari diusulkan proposal dengan tujuan untuk mendapatkan pendanaan kegiatan ini, termasuk didalamnya pembentukan tim PKM. Pada Tahap ini juga dijalin komunikasi dengan Mitra, dalam hal ini adalah perusahaan dengan status IKM dengan nama HALISA yang terletak di Jakarta Barat.

Tahap Pengorganisasian; pada tahap ini dilakukan pengaturan waktu pelaksanaan PKM mulai dari observasi awal serta melakukan koordinasi antar-tim dalam menyiapkan berbagai perlengkapan pelatihan dan sarana yang diperlukan.

Tahap Pelaksanaan; tahap ini terbagi atas tahap pelaksanaan awal dan tahap pelaksanaan sosialisasi. Dimana tahap pelaksanaan awal merupakan serangkaian kegiatan yang dilakukan oleh TIM PKM mulai dari pembuatan kuesioner sampai pengolahan data berbasis analisis conjoint sehingga bisa diperoleh attribut yang menjadi kebutuhan dari pelanggan telur gabus IKM HALISA. Sedangkan tahap pelaksanaan sosialisasi adalah tahapan dimana hasil yang diperoleh oleh TIM PKM direalisasikan dalam suatu bentuk rancang ulang produk dan disampaikan kepihak IKM HALISA untuk mendapatkan feedback terkait hasil rancang ulang yang dibuat oleh tim.

Tahap Pengendalian; tahap ini merupakan tahap akhir dimana diperoleh hasil pengembangan produk baru berupa perancangan ulang produk sesuai dengan yang diinginkan pelanggan serta melakukan pendampingan untuk membantu memberikan konsultasi solusi atau rekayasa design produk yang baru dimana dapat langsung diterapkan pada mitra. Pada tahap ini juga didapatkan feedback yang disampaikan secara lisan dari pihak mitra dan juga hasil dari peningkatan penjualan setelah dilakukan penerapan dari hasil pengembangan produk baru tersebut. Adapun yang menjadi Target luaran dari PKM ini adalah Memberikan pendampingan dan sosialisasi tentang tujuan pengembangan produk dan pengaruhnya terhadap peningkatan penjualan produk pada perusahaan penghasil makanan ringan jenis telur gabus dalam hal ini adalah IKM HALISA.

\section{HASIL DAN PEMBAHASAN}

Kegiatan PKM ini diawali dengan mengamati masalah yang terjadi pada IKM Halisa melalui wawancara dengan pihak mitra dimana diagram keterkaitan masalah dapat dilihat pada Gambar 1. Setelah itu dilanjutkan dengan melakukan pembuatan kuesioner pendahuluan untuk survey awal dimana respondennya terdiri dari para pelanggan makanan ringan di jabodetabek. Setelah dilakukan survey pendahuluan kemudian dilanjutkan dengan pembuatan kuesioner conjoin 
untuk mengetahui atribut yang dianggap penting oleh konsumen. Pada tahap pengolahan data kuesioner pendahuluan adapun data yang digunakan antara lain, data responden, persentase atribut pertimbangan, dan hasil pertanyaan khusus mengenai produk. Selanjutnya, data akan diolah untuk menentukan preferensi konsumen.

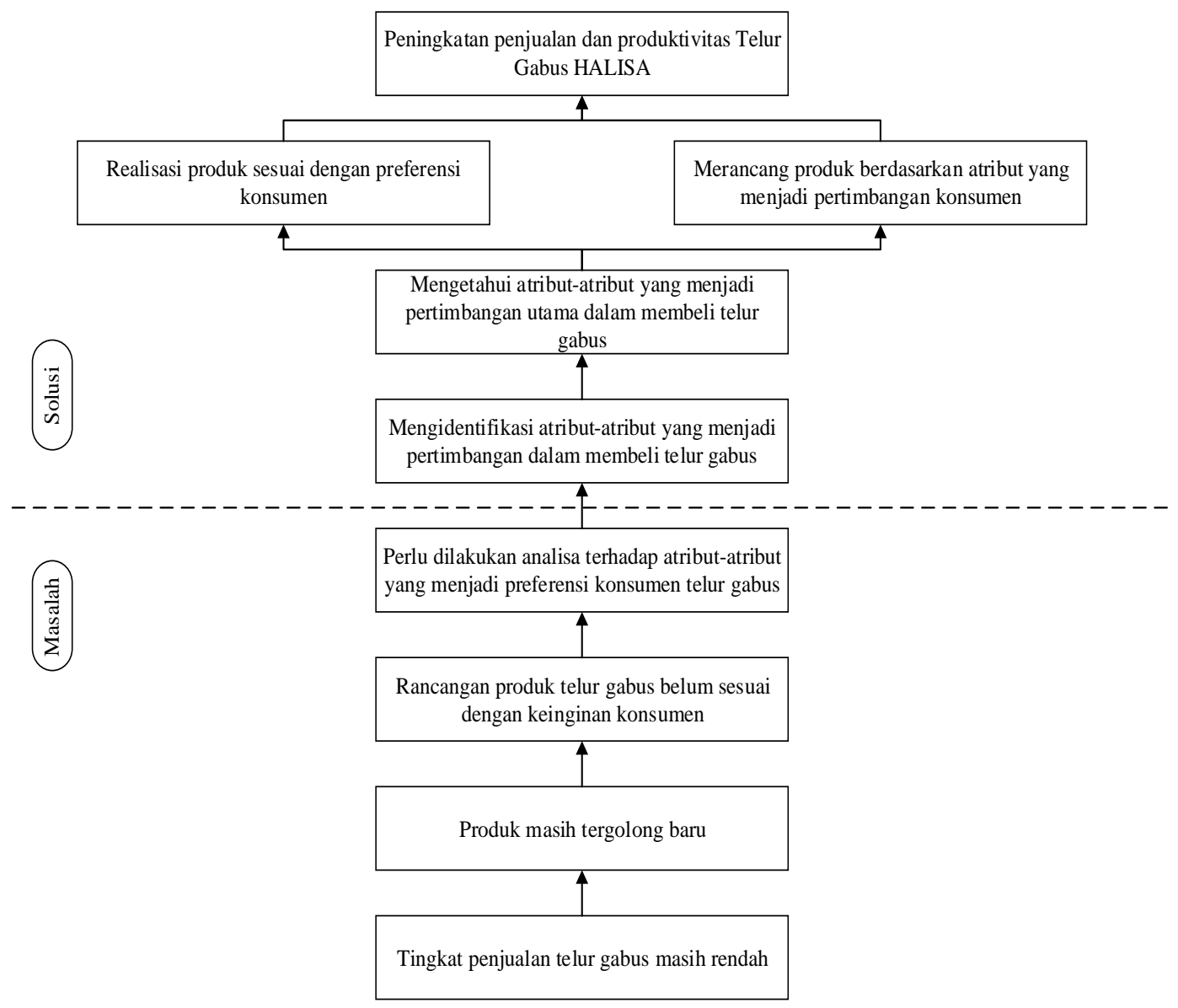

Gambar 1. Diagram Keterkaitan Masalah

Berdasarkan hasil kuesioner yang sudah diolah maka diperoleh rancangan produk baru dengan preferensi konsumen sebagai berikut yaitu dari sisi telur gabus diharapkan produk dirancang dengan tekstur padat dan memiliki varian rasa telur gabus dengan kombinasi varian rasa asin serta varian rasa pedas. Isi produk diutamakan sebanyak 110 gr. Kemudian dari apek kemasan diperoleh preferensi konsumen cara membawa dan desain kemasan yaitu dengan cara digenggam dan memiliki desain sticker yang menutupi setengah kemasan. Rancangan produk baru dapat dilihat pada Gambar 2. Dari rancangan kemasan yang telah diterapkan sebelumnya terdapat perbedaan pada material kemasan yaitu plastik transparan sehingga isi produk dapat terlihat dari segala sisi kemasan. Pada kemasan produk telur gabus lama dimensinya adalah lebar $14 \mathrm{~cm}$ dan tinggi $22 \mathrm{~cm}$ dan mampu menampung produk seberat 100 gr. Pada material kemasan baru terbuat dari bahan kombinasi plastik transparan dan aluminium yang menjamin isi produk lebih tahan lama dibanding material sebelumnya. Kemasan kombinasi yang digunakan memiliki ukuran lebih besar dengan lebar $16 \mathrm{~cm}$ dan tinggi $24 \mathrm{~cm}$. Ukuran yang lebih besar membuat isi produk bertambah dari 100 gr menjadi 110 gr. 


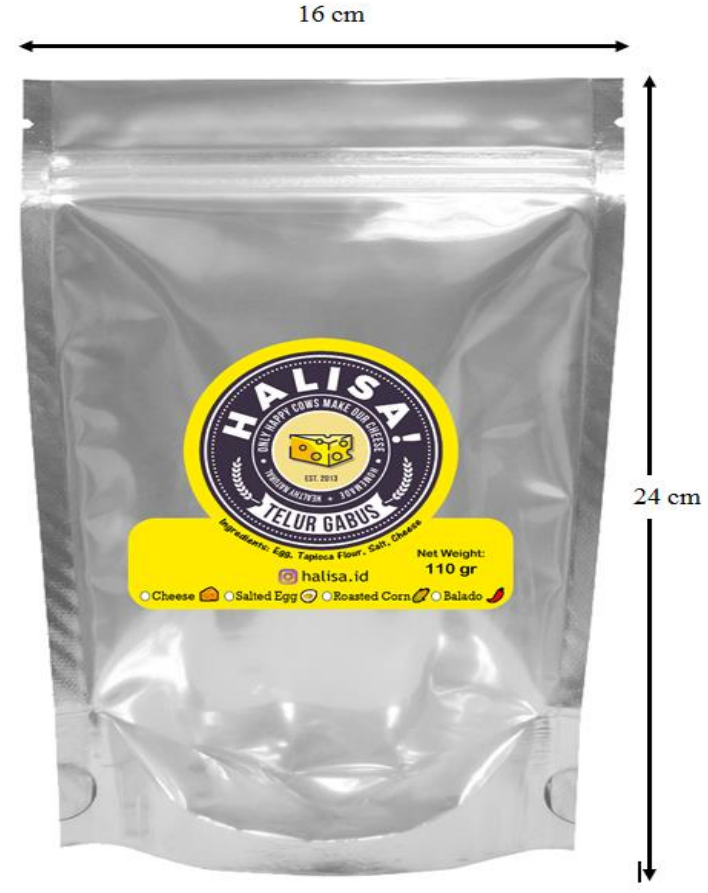

Gambar 2. Hasil Pengembangan Produk

Berdasarkan hasil rancangan yang diperoleh dengan menggunakan metode konjoin analisis maka langkah selanjutnya adalah melakukan sosialisasi terhadap hasil rancangan baru kepada Mitra. Sosialisasi ini bertujuan untuk mengenalkan perbedaan produk yang baru dengan yang lama seperti dapat dilihat pada Tabel 1 dan Gambar 2 sebagai upaya untuk peningkatan penjualan dari produk telur gabus IKM HALISA. Sosialisasi dilakukan dengan memperkenalkan kepada mitra tentang langkah yang dilakukan Tim PKM mulai studi pendahuluan sampai dengan memperoleh produk hasil rancangan baru. Pada Sosialisasi ini juga diperkenalkan spesifikasi produk kemasan yang baru seperti dapat dilihat pada Tabel 2.

Setelah dilakukan sosialisasi perihal hasil rancang ulang kemasan kemudian oleh pihak IKM HALISA dilakukan implementasi untuk mengetahui seberapa besar peningkatan penjualan yang terjadi dengan adanya perubahan yang dilakukan oleh TIM PKM. Setelah diperoleh hasil penjualan kemudian dilakukan evaluasi hasil kegiatan dengan cara mendengarkan pendapat dari perwakilan IKM HALISA secara lisan dengan tujuan untuk memperoleh masukan mengenai kegiatan PKM yang telah dilaksanakan dan harapan dari pihak IKM HALISA terhadap keberlanjutan dari program PKM yang telah dilakukan.

Proses Evaluasi hasil kegiatan ini merupakan tahap akhir dari rangkaian kegiatan PKM yang dilakukan. Evaluasi hasil kegiatan PKM ini juga dapat dijadikan umpan balik kepada Tim PKM UNTAR sebagai upaya peningkatan mutu pelaksanaan kegiatan PKM pada program serupa untuk kegiatan selanjutnya. Evaluasi dilakukan hanya secara lisan dikarenakan sifat dari kegiatan ini berupa pendampingan dan sosialisasi hasil rancangan produk baru. Kegiatan ini diakhiri dengan penyerahan produk hasil rancangan baru yang merupakan hasil dari proses pendampingan selama periode waktu yang telah ditentukan kepada pihak IKM HALISA secara simbolis. Rangkaian kegiatan sosialisasi dan evaluasi kegiatan dapat dilihat pada Tabel 3.

Tabel 1. Perbandingan Spesifikasi Produk Telur Gabus Kemasan Lama dan Kemasan Baru 



Gambar 3. Hasil perbandingan kemasan sebelum dan sesudah pengembangan

Tabel 2. Spesifikasi Produk Baru 


\begin{tabular}{|c|c|c|}
\hline No. & Gambar & Keterangan \\
\hline 1. & & Produk Tampak Samping \\
\hline 2. & & Produk Tampak Belakang \\
\hline 3. & & Seal Kemasan Disobek \\
\hline 4. & & Zipper pada Kemasan Dibuka \\
\hline 5. & & Produk Setelah Dibuka \\
\hline
\end{tabular}




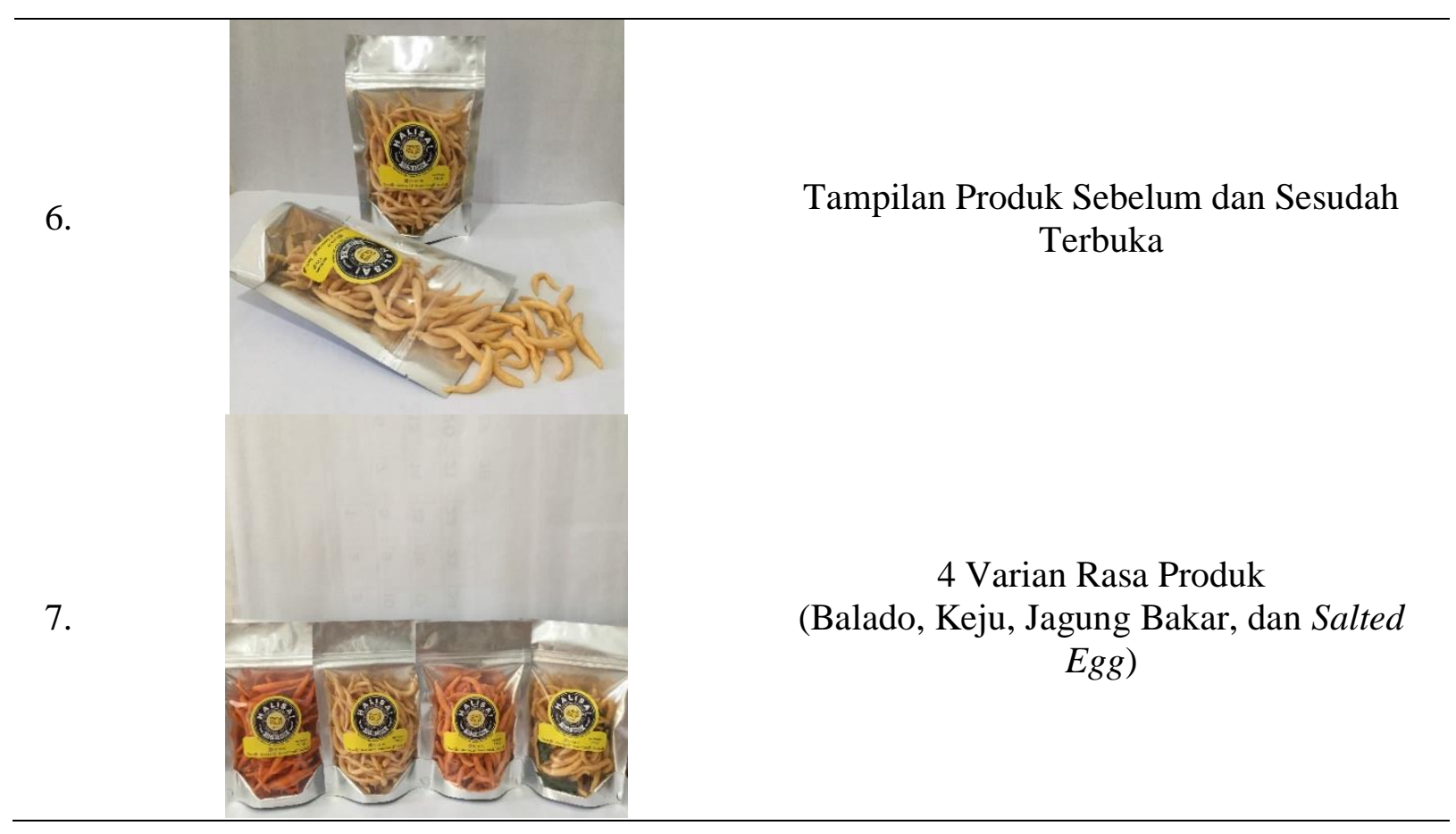

Tabel 3. Susunan Acara Sosialisasi Hasil Rancangan Produk Baru

\begin{tabular}{clc}
\hline Waktu & \multicolumn{1}{c}{ Acara } & PIC \\
\hline & $\begin{array}{c}\text { Kata Sambutan dan Pembukaan: } \\
\text { 09:00-09:30 }\end{array}$ & Ketua Tim Abdimas \\
& $\bullet$ Perwakilan dari IKM HALISA & MC \\
\hline 09:30-11:30 & $\begin{array}{l}\text { Introduction of Conjoint Analysis dan } \\
\text { pengenalan Spesifikasi Produk dengan } \\
\text { Kemasan Baru }\end{array}$ & \\
\hline $11: 30-11: 45$ & Serah Terima Hasil Rancangan Produk Baru \\
\hline $11: 45-12: 00$ & $\begin{array}{l}\text { Evaluasi Kegiatan, Serah terima Sertifikat dan } \\
\text { cindera mata, penutupan dan Foto Bersama }\end{array}$ & \\
\hline
\end{tabular}

Acara diawali dengan pembukaan dan kata sambutan dari Ketua Tim PKM dan perwakilan dari IKM HALISA. Kemudian dilanjutkan dengan pengenalan dan upaya yang telah dilakukan oleh Tim PKM hingga terbentuk hasil rancangan baru. Setelah itu dilakukan serah terima hasil rancangan produk baru secara simbolis oleh ketua Tim PKM dan dilanjutkan serah terima sertifikat oleh Ketua Program Studi Sarjana Teknik Industri UNTAR kepada perwakilan dari IKM HALISA sebaga ucapan terima kasih atas kerjasama yang telah dilakukan. Acara terakhir adalah evaluasi kegiatan secara lisan dilanjutkan penutupan dan foto bersama Tim PKM dengan Mitra dalam hal ini adalah IKM HALISA. Serangkaian kegiatan tersebut dapat dilihat pada Gambar 4 sampai dengan Gambar 7.

Hasil yang diperoleh dari kegiatan ini selain rancangan produk baru juga diperoleh hasil berupa adanya peningkatan penjualan dari produk telur gabus IKM HALISA. Hasil dari peningkatan penjualan dan perbandingan penjualan dengan produk lama dapat dilihat pada Tabel 4. Adanya perubahan material kemasan dan banyaknya isi produk, tentunya akan berpengaruh 
pada pendapatan produsen. Modal perlu ditambahkan sebesar 21,33\% terkait dengan perubahan kemasan. Jika produk dengan kemasan baru dipasarkan dengan harga jual yang sama, maka keuntungan yang diperoleh akan menurun sebanyak 20,19\%. Oleh karena itu, diperlukan uji pasar untuk melihat respon konsumen terhadap rancangan produk baru. Apabila dengan rancangan produk baru permintaan meningkat, maka keuntungan yang diperoleh juga akan meningkat.

Berdasarkan data hasil pengujian pasar terjadi peningkatan permintaan produk sebanyak 296\%. Hal ini menunjukkan bahwa perancangan produk yang sesuai dengan preferensi konsumen dapat meningkatkan permintaan produk yang akan berpengaruh pada peningkatan produktivitas dan keuntungan yang diperoleh produsen.

Tabel 4. Hasil Perbandingan Jumlah Penjualan Pada Periode Tertentu Sebelum dan Sesudah Perbaikan Rancangan

\begin{tabular}{ccc}
\hline Periode & $\begin{array}{c}\text { Sebelum } \\
\text { (Desember 2017) }\end{array}$ & $\begin{array}{c}\text { Sesudah } \\
(\text { Desember 2018) }\end{array}$ \\
\hline Jumlah Penjualan (Bungkus) & 25 & 99 \\
\hline
\end{tabular}



Gambar 4. Kata Sambutan dan Pembukaan Kegiatan Sosisalisasi

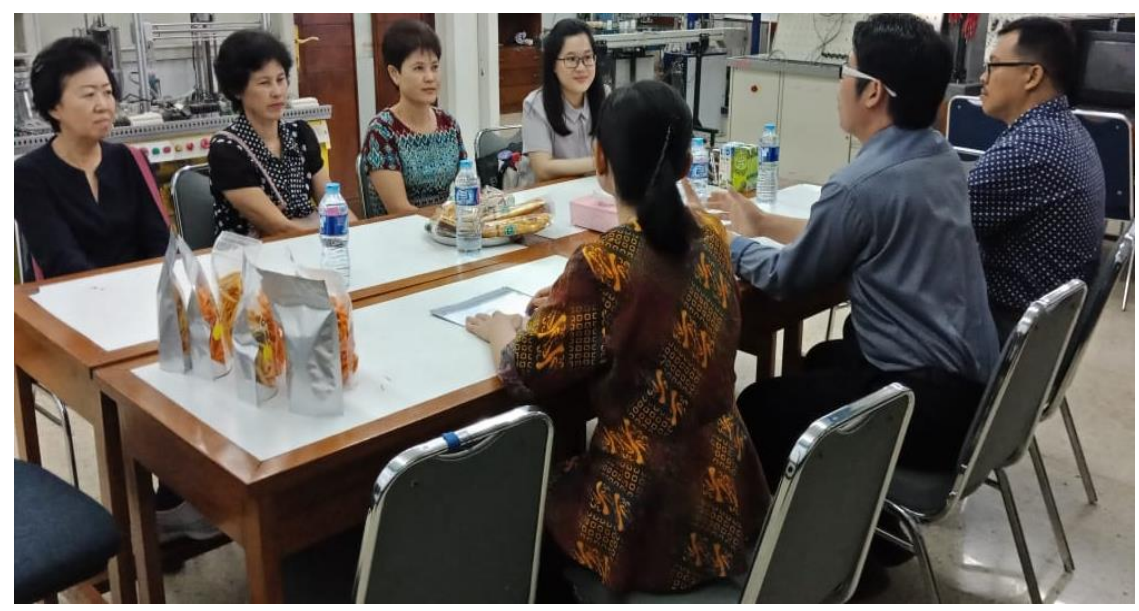

Gambar 5. Pengenalan Spesifikasi Produk dengan Kemasan Baru 


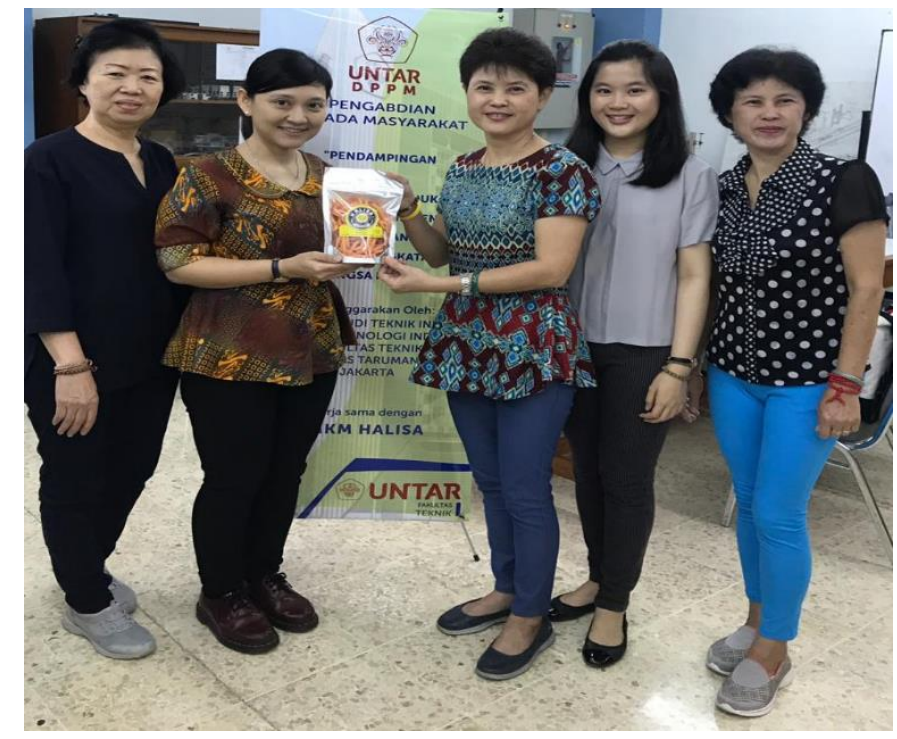

Gambar 6. Serah Terima Hasil Rancangan Produk Baru

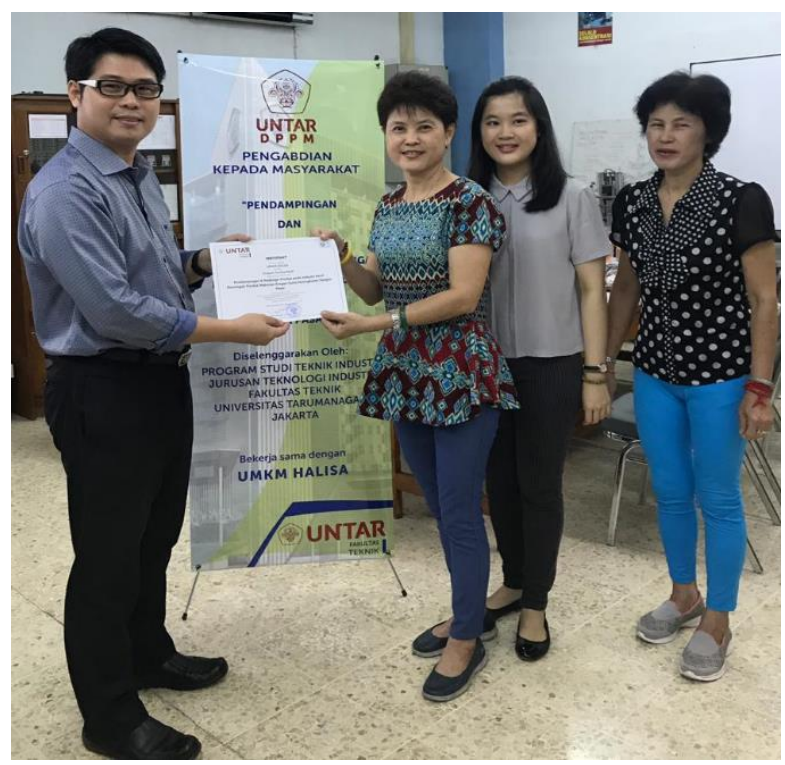

Gambar 7. Penyerahan Sertifikat Kepada Mitra Sebagai Ucapan Terima Kasih

\section{KESIMPULAN}

Kegiatan PKM ini telah dilaksanakan dengan baik. Adapun luaran yang dihasilkan adalah berupa pendampingan dan perancangan ulang produk serta realisasi pengembangan dari produk makanan ringan telur gabus berbasis Analisis Konjoin pada IKM HALISA. Adapun pengembangan yang dilakukan perdasarkan preferensi konsumen adalah pada kemasannya. Sosialisasi dari produk baru pun telah dilaksanakan dan ditanggapi dengan baik oleh pihak mitra. Selain itu dengan adanya pengembangan produk baru juga terbukti dapat meningkatkan penjualan produk telur gabus IKM HALISA. Pihak mitra mengucapkan terima kasih atas bantuan pendampingan dan sosialisasi tersebut dan menanggapi bahwa keseluruhan pelaksanaan kegiatan telah berjalan sangat baik dan bermanfaat untuk mereka. 


\section{REFERENSI}

Hair, J. F., et al. Multivariate Data Analysis: A Global Perspective, 7th edition. New York: Prentice Hall, 2009.

Kosasih, W., L. L. Salomon, and R. Hutomo. Using conjoint and cluster analysis in developing new product for micro, small and medium enterprises (SMEs) based on customer preferences (Case study: Lampung province's banana chips). AIP Conference Proceedings. Vol. 1867. No. 1. AIP Publishing, 2017.

Kotler, P. Manajemen Pemasaran Analisis, Perencanaan, Implementasi dan Kontrol. Jakarta: Prenhallindo, 1997.

Salomon, L. L., W. Kosasih, and N. L. Saputra. Strategi Pengembangan Plastic Shopping Bag Berdasarkan Preferensi Konsumen dengan Pendekatan Metode Kansei Engineering (Studi Kasus: PT Era). Jurnal Teknik dan Ilmu Komputer. Vol. 4. No. 14 (Juni 2015): 175-187.

Surjandari, I. Conjoint Analysis: Konsep dan Aplikasi. Jakarta: Penerbit Universitas Trisakti, 2010.

Tohari, Amin. Analisis Cluster Psikografis Konsumen Kediri Town Square (Cluster Analysis Psychographic Consumers Kediri Town Square). Jurnal Matematika dan Pendidikan Matematika. Vol. 1. No. 2. (September 2016): 109-118.

www.mondelezinternational.com (diakses pada tanggal 30 Agustus 2018) 